\section{EDUCATION}

Research, Innovation and Solutions on-line ${ }^{\circledR}$

\section{Electronic Journal of Research}

in Educational Psychology

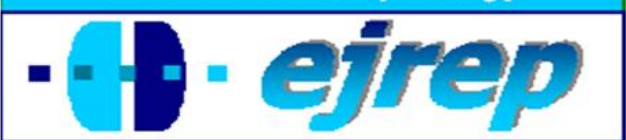

Editorial EOS

\title{
Assessing the link between executive functions and aggressive behaviours of children who are deaf: Impact of early special education
}

Rafet Firat Sipal ${ }^{1}$ \& Pinar Bayhan ${ }^{1}$

${ }^{1}$ Department of Child Development, Hacettepe University, Ankara

Turkey

* This study is produced from the doctoral dissertation of the first author

Correspondence: Rafet Firat Sipal. Hacettepe University, Department of Child Development, Sihhiye, Ankara 06100. Turkey. E-mail: fsipal@hacettepe.edu.tr

(C) Education \& Psychology I+D+i and Editorial EOS (Spain) 


\begin{abstract}
Introduction. Relation between constructing complex mental structures and language skills cause delays in development of executive functions of deaf children. When the importance of language skills in development of executive functions and frequency of aggressive behaviours of deaf children are considered, investigation of executive functions of deaf children may explain their aggressive behaviours.
\end{abstract}

Method. 82 children of 10-14 ages were analyzed within 2 groups; students with and without early special education background. For measuring aggressive behaviours Buss-Durke Hostility Inventory (BDHI) and for measuring executive functions Wisconsin Card Sorting Test (WCST) were used.

Results. Preschool special education has no significant effect on aggressive behaviours but on executive functions. Aggression has no significant effect of any variables analyzed in the present study whereas early special education background and gender has significant effects on the development of executive functions.

Discussion and Conclusions. From a theoretical perspective, the findings support the interdependence of language and executive functions. Therefore, one can say that early special education has positive effects on cognitive development of deaf children, however, lacks of supporting social development during adolescence.

Keywords: Hearing impairment, executive functions, aggression, aggressive behaviours, language development

Received: 05/21/10 Initial Acceptance: 05/24/10 Definitive Acceptance: 11/04/10 


\section{Valoración de la relación entre funciones ejecutivas y con- ductas agresivas de niños sordos: impacto de la educación especial temprana}

\section{Resumen}

Introducción. La relación entre la construcción de complejas estructuras mentales y lingüísticas de los niños sordos causan retrasos en el desarrollo de las funciones ejecutivas. Cuando la importancia de las competencias lingüísticas en el desarrollo de las funciones ejecutivas y la frecuencia de los comportamientos agresivos de los niños sordos son considerados, la investigación de las funciones ejecutivas de los niños sordos pueden explicar sus conductas agresivas.

Método. Un total de 82 niños de 10-14 años de edad fueron analizados en dos grupos: estudiantes con y sin antecedentes tempranos de educación especial. Para la medición de las conductas agresivas se utilizó el inventario de Buss-Durke Hostildad (BDHI) y para medir las funciones ejecutivas el Wisconsin Card Sorting Test (WCST).

Resultados. La educación preescolar especial no tiene efecto significativo en los comportamientos agresivos, sino en las funciones ejecutivas. La agresión no tiene ningún efecto significativo en las variables analizadas en el estudio mientras que la historia en educación especial y el género tienen efectos significativos en el desarrollo de las funciones ejecutivas.

Discusión y Conclusiones: Desde un punto de vista teórico, los resultados apoyan la interdependencia del lenguaje y funciones ejecutivas. Por lo tanto, se puede decir que inicialmente la educación especial tiene efectos positivos sobre el desarrollo cognitivo de los niños sordos, sin embargo, estos carecen de un desarrollo social durante la adolescencia.

Palabras clave: discapacidad auditiva, las funciones ejecutivas, la agresión, las conductas agresivas, el desarrollo del lenguaje

Recibido: 21/05/10 Aceptación Inicial: 24/05/10 Aceptación Definitiva: 04/11/10 


\section{Introduction}

Spoken language development in severely or profoundly deaf children is typically delayed compared with their hearing counterparts (Baker-Hawkins \& Easterbrooks, 1994). Regarding to their delay in typical development, children who are deaf experience difficulties when communicating with their families, hearing peers, and the wider society (Hindley, 2000; Meadow-Orlans \& Erting, 2000). Therefore, it is important for the children who are deaf to benefit early special education in order to be supported in terms of hearing and language. Early special education is vital for all children with disabilities; particularly for children who are deaf, early intervention is the key component for developing the language. Children enrolled in early special education within the first year of life have been shown to have language development within the normal range of development at 5 years of age (Moeller, 2000). Therefore, once any degree of hearing loss is diagnosed in a child, a referral should be initiated to an early special education program as soon as possible after the confirmation of hearing loss (Yoshinago-Itano \& Sedey, 1998; Young, Hunt, Carr, Hall, McCracken, Skipp \& Tattersall, 2005).

Even though early special education supports children who are deaf in terms of hearing and language, it's well known that they are more prone to present behavior problems such as aggression than children with normal hearing due to their deficiency in communication skills (Moeller, 2000; Shannon \& Anderson, 2008). The estimated prevalence of such problems in deaf children and adolescents varied widely in early studies, from 15\% (Rutter, Graham, \& Yule, 1970) to 54\% (Fundudis, Kolvin, \& Garside, 1979), showing a preponderance of behavioral or emotional disorders. Besides, recent studies echo those findings and discuss the higher rate of aggression related to communication skills in hearing impaired children (Hooper, Swartz, Wakely, deKruif \& Montgomery, 2002; Howley \& Howe, 2004). Moreover, Turkish literature on the behavior problems of children who are deaf presents similar findings. A study by Sunal and Cam (2005) shows that prevelance of behavior problems in deaf children has been found to be around 29\%. Similarly, Sipal (2002) found that wast majority of deaf children in his study were to present high rates of externalizing behaviors than their normally hearing peers. A national research by Turkish Statistical Institute supports the arguments (TUIK, 2002). Findings of the research show that $19 \%$ of the individuals with hearing disabilities present problem behaviors. 
Studies on aggression in hearing impaired children show evidence that such aggressive behaviors are often results of communication deficits (Andersson, Olsson, Rydell \& Larsen, 2000). However, aggressive behaviors are the results of more complex mental processes including ability to control the automatic behaviors, inhibitory control and self regulatory skills (Esteban, Sidera, Serrano, Amado \& Rostan, 2010; Lundy, 2002; Marlowe, 2000). Therefore, it is important to assess the related processes that have control on aggressive behaviors such as "executive functions" (EF) in order to have deeper understanding on the aggressive behaviors of children who are deaf.

The construct of executive function (EF) encompasses the organizational and selfregulatory skills required for goal-directed, non-automatic behavior. It has been variously described as including planning, initiating, monitoring, and flexibly correcting actions according to feedback; sustaining and shifting attention; controlling impulses and inhibiting prepotent but maladaptive responses; selecting goals and performing actions that may not lead to an immediate reward, with a view to reaching a longer term objective; holding information in mind whilst performing a task (working memory); and creatively reacting to novel situations with non-habitual responses (Hughes \& Graham, 2002; Shallice \& Burgess, 1991; Welsh \& Pennington, 1988). Recent theoretical conceptualizations of EF suggest that it is not a unitary function, but encompasses a range of dissociable skills, such that it is possible for an individual to fail on some executive tasks whilst succeeding on others (Baddeley, 1998; Garavan, Ross, Murphy, Roche, \& Stein, 2002; Miyake et al., 2000). Different EF skills may follow independent developmental pathways, some of which may be more strongly associated with language (and thus more affected by the consequences of deafness) than others.

No studies have examined EF comprehensively in deaf children, although a number have included tests that assess some EF components as part of wider investigations. There is some evidence for impaired attention in deaf children compared with their hearing peers (Khan, Edwards, \& Langdon, 2005; Mitchell \& Quittner, 1996). Besides, planning and problem solving have also been found to be poorer in deaf children compared with hearing children (Das \& Ojile, 1995; Marschark \& Everhart, 1999).

Development of language and that of EF is considered to closely interact. Given the wealth of research examining the impact of deafness on the language acquisition of deaf children, it is surprising that limited research has been carried out deaf children's EF, and that 
there are such few studies explicitly examining the relationship between language skills and EF in deaf children. Many of the existing studies have examined deaf children's performance on only a few of the EF subcomponents. Moreover; not only in international literature but also in Turkish literature, studies on executive functioning focus on medical conditions such as alzheimer, schizophrenia (Karakas \& Aydin, 1999; Sismanlar, Coskun, Agaoglu, Zaimoglu, Karakaya \& Yavuz, 2009; Yesilyurt, Maner, Ceylan, Guler, Turkcan \& Satmis, 2008), as well as attention deficit and hyperactivity disorders (Kilincaslan, 2010; Oner \& Aysev, 1999). Those studies commonly take place in Turkish psychiatry literature, however; literature on educational psychology lacks of this information. There is a gap of knowledge about the affect of executive functions on behaviors of children with special educational needs in order to understand the origins of their antisocial behaviors and to support them in educational settings. Therefore, it is important to find out the possible link between deafness, EF and aggression in children who are deaf for understanding the impact of EF on their aggressive behaviors. For that purpose, we tested 82 children who are deaf in order to assess their EF and aggressive behaviors. We did not include a comparison sample in our study, instead, we grouped children in two as; with and without preschool special education experience. The rationale for this grouping is the well documented positive effect of early special education on the language skills of children who are deaf. As it is previously reported in earlier studies that children with language impairments present lower EF compared to children with typical language development, comparing children who are deaf with different language abilities will provide precious information on the relationship between language skills, aggressive behaviors and $\mathrm{EF}$ of children who are deaf.

\section{Method}

\section{Participants}

Present study was conducted in the metropolitan area of Ankara where is the capital city of Turkey. All segregated schools for the deaf in Ankara were contacted for participation. The purpose and the content of the study was explained and discussed with the principles of the schools. However, one of the schools refused to participate in the study due to the busy schedule. With the collaboration of the school psychologists, researchers made a list of eligible children and their parents were sent informed consent forms for their approval for partici- 
pating in the study. Within the eligible 123 children 41 of them returned a negative response, thus 82 children of 10-14 ages were recruited for the study. Within the participants 42 children were boys and 40 were girls with a mean age of $11.91(S D=1.44)$ All the children had bilateral, sensory-neural $(\mathrm{S} / \mathrm{N})$, severe hearing loss (71-95 dB) as they were all attending classes in segregated schools for the deaf. 39 of the children (47.6\%) had early special education history whereas 43 of them $(52.4 \%)$ not. Children with a secondary disability were not included in the study. The study protocol was approved by Ministry of Education Research Ethics Committee.

The reasons for not participating in the study can be determined in 4 cases: 25 of the families were not interested in the study $(60.97 \%), 7$ of the families reported that they do not think their child will benefit the outcomes (17.07\%), 6 of the families refused to participate without any reasons (14.63\%) and 3 families did not return the forms $(7.31 \%)$.

\section{Instruments}

Demographic information form: A demographic information form was used to gather information about the family, child, child's education and child's communicative behaviors.

Peabody Picture Vocabulary Test (PPVT): PPVT was first developed by Dunn in 1959 (as cited in American Guidance Services, AGS, 2005) for assessing the vocabulary knowledge of children as well as their receptive language. The PPVT is an individual language performance test, orally administered in 20 minutes or less. No reading is required by the client, and scoring is rapid and objective. Item responses are made by pointing or multiple choice selections, dependent upon the subject's age. Although desirable, no special training is required to properly administer and score the PPVT. The PPVT provides an estimate of the client's verbal performance and has been administered to groups who had reading or speech problems, had mental retardation, or were emotionally withdrawn. For its administration, the examiner presents a series of pictures to each client. There are four pictures to a page, and each is numbered. The examiner states a word describing one of the pictures and asks the client to point to or say the number of the picture that the word describes. PPVT was standardized for Turkish language by Katz and collegues in 1974 (as cited in Oner, 1997). For Turkish standardization, 1440 children (2-12 years) living in urban, suburban and rural areas 
were tested and norm tables were listed according to the scores. Reliability of Turkish standardization of PPVT was found to have range of .71 - .81.

Buss - Durke Hostility Inventory (BDHI): BDHI is an inventory consisting of 75 true-false items, is generally regarded as the most carefully designed psychometric measure of hostility and aggression. In the development of the inventory, hostility was conceptualized as multidimensional and BDHI subscales were constructed to assess seven hypothesized components of hostility: Assault, indirect, irritable, negativism, resentment, suspicion and verbal. There is also a subscale to measure guilt (Spielberger, Reheiser, \& Sydeman, 1995). Turkish form of Buss - Durke Hostility Inventory was standardized by Askin (1981) and reported a very high internal consistency, estimated by Cronbach's alpha ,94.

Wisconsin Card Sorting Test (WCST): WCST is developed by Berg (1948), and revised by Heaton (1981) to assess executive functions in terms of planning, organizing, abstract thinking, conceptualizing, maintaining and adapting cognitive constructs and inhibiting impulsive responses (Lezak, 1995; Spreen \& Strauss, 1998). Turkish standardization and validation of WCST for adults was reported by Karakas, Eski and Basar (1996) and for children between 615 ages (75-182 months) by Erol, Akcakin, Akozel-Sahin, Dikmeer-Altinoglu \& Irak (2006). As structure of WCST is not available for reliability analysis, factorial analyses were run for Turkish standardization. Results showed that WCST for Turkish population (both for children and adults) presents two main factors as well; (1) perseveration and (2) working memory, (KMO .83, Barlett's $\left.\mathrm{X}^{2}=9211.91, \mathrm{p}=.001\right)$.

\section{Procedure}

The procedure took place at the schools during day time under the supervision of the teachers. Children were informed about the purpose of the study and the voluntary nature of participation was explained. None of the children refused to participate in the study. School records were used for grouping children with and without special education background. Children with early special education background formed Group 1 and children without early special education background formed Group 2. Even though Group 1 was expected to have better language performance, both groups were tested with PPVT by authors in order to assess their language performance before the study procedure was applied. Thus, the data gathered from Group 1 also points the group with "better language performance". BDHI was applied 
orally for every child in both groups by the first author and the sessions took 30-35 minutes. Concerning the attention spans of the children, WCST was applied in a different session on the following day of BDHI session by the first author. WCST sessions took place in the test rooms of the schools where are silent rooms with minimum materials which minimize the distraction of children. WCST sessions ended when the children successfully matched the cards (10 for every category) in six matching categories (colour, shape, quantity, colour, shape, quantity) or when the cards ran out. Sessions took around 20-25 minutes for the children participating in the study. Children were given stickers of stars and smiley faces to reward their efforts and sustain motivation. The same number of stickers was offered to each child, across the two groups. Care was taken to give instructions with maximum clarity, making sure that children could see the tester's lip movements, and that their attention was appropriately focused. The same instructions were given to all participants. Tests were always administered in the same order, to ensure that potential test-order effects would be constant across groups.

\section{Results}

Preliminary analyses of the participants are shown in Table 1 . Table 2 provides the descriptive statistics for each group of children on the language test. As hypothesized, a significant effect of group emerged on children's raw score on the PPVT $\left(\mathrm{F}_{[2,65]}=29.89, p<.001\right)$ Followup ANOVAs with Bonferroni corrections revealed that, as expected, Group 1 scored significantly higher than Group $2\left(\mathrm{~F}_{[1,41]}=50.93, p<.001\right)$. 
Table 1. Preliminary analysis of the participants in the study

\begin{tabular}{lcccc}
\hline Variable & $N$ & $\%$ & $S D$ & $M$ \\
\hline Age & & & & \\
10 & 19 & $\% 23,2$ & & \\
11 & 16 & $\% 19,5$ & & \\
12 & 15 & $\% 18,3$ & 1,44 & 11,91 \\
13 & 17 & $\% 20,7$ & & \\
14 & 15 & $\% 18,3$ & \\
Gender & & & \\
Girl & 40 & $\% 48,8$ & \\
Boy & 42 & $\% 51,2$ & \\
Early special education background & & \\
Had early special ed. & 39 & $\% 47,6$ & \\
Did not have early special ed. & 43 & $\% 52,4$ & \\
Duration of early special education & & \\
Never & 43 & $\% 52,4$ & \\
Less than 1 year & 10 & $\% 12,2$ & \\
1-2 years & 5 & $\% 6,2$ & \\
2-3 years & 2 & $\% 2,4$ & \\
More than 3 years & 22 & $\% 26,8$ & \\
Communication choices with family & & \\
Sign language & 16 & $\% 19,5$ & \\
Oral language & 16 & $\% 19,5$ & \\
Both & 50 & $\% 50$ & \\
Reactions to communication barriers & & \\
Repeatedly tries to express & 63 & $\% 76,8$ & \\
Gets angry & 10 & $\% 12,2$ & \\
Gives up & 6 & $\% 7,3$ & \\
Other & 3 & $\% 3,7$ & \\
\hline
\end{tabular}

Table 2. Children's performance on Peabody Picture vocabulary Test

\begin{tabular}{|c|c|c|c|c|c|}
\hline \multirow[t]{2}{*}{ Group } & \multirow[t]{2}{*}{$n$} & \multicolumn{2}{|c|}{$\begin{array}{l}\text { PPVT raw } \\
\text { scores }\end{array}$} & \multicolumn{2}{|c|}{$\begin{array}{l}\text { PPVT standard } \\
\text { scores }\end{array}$} \\
\hline & & $M$ & $S D$ & $M$ & $S D$ \\
\hline $\begin{array}{l}\text { Group } 1 \\
\text { (with early special } \\
\text { education background) }\end{array}$ & 39 & 56.3 & 14.4 & 67.2 & 11.7 \\
\hline $\begin{array}{l}\text { Group } 2 \\
\text { (without early special } \\
\text { education background) }\end{array}$ & 43 & 50.1 & 12.7 & 48.4 & 14.3 \\
\hline
\end{tabular}

Results on aggression scores in Table 3 show that mean scores of boys $(M=43.49$, $S D=2.38)$ were higher than the girls $(M=39.41, S D=2.09)$, however, that finding remained insignificant statistically ( $p=.428$ ). Similarly, the group without early special education back- 
ground had higher scores on aggression scale $(M=43.91, S D=1.98)$ however, that difference was found insignificant ( $p=.325)$. Aggression scores were also tested according to age differences. Interestingly, results showed that children showed no significant difference for aggression scores according to their ages $(p=.903)$.

Table 3. Impact of gender, age, and early special education background on aggression scores

\begin{tabular}{lccccccc}
\hline \multicolumn{1}{c}{ Variable } & $N$ & $m$ & $S$ & Mann Whitney $U$ & Wilcoxon $W$ & $X^{2}$ & $p$ \\
\hline Gender & & & & & & & \\
Girl & 42 & 39,41 & 2,09 & 756,5 & 1576,5 & .428 \\
Boy & 40 & 43,49 & 2,38 & & & \\
Total & 82 & & & & & \\
Special ed. & & & & & & \\
Had & 39 & 38,85 & 2,48 & 735,0 & 1515,0 & \\
Did not have & 43 & 43,91 & 1,98 & & & \\
Total & 82 & & & & & \\
Age & 19 & 42,16 & & & & \\
10 & 16 & 37,81 & & & & \\
11 & 15 & 43,60 & & & & \\
12 & 17 & 39,26 & & & & \\
13 & 15 & 45,03 & & & & \\
14 & 82 & & & & & \\
Total & \multicolumn{7}{c}{ Note: m. mean value of the scores gathered from BDHI, S. standard deviation of BDHI scores }
\end{tabular}

Factor analysis was applied for all WCST scores with basic components analysis (Table 4). Double factor analysis and varimax rotation results showed that, $67.98 \%$ of the total variance was explained by two factors According to this finding, first factor includes number of total errors, conceptual level response percentage, number of perseverative errors, number of perseverative responses, trials administered; perseverative error percentage, number of nonperseverative errors and number of conceptual level response and those scores explained $39.49 \%$ of the total variance. Second factor explained $28.48 \%$ of the total variance with WCST scores trials to complete first category, learning to learn, categories completed, total correct and failure to maintain set.

Combined affect of age, gender, and early special education background on executive functioning was tested with a general linear model. Model was run for each WCST score as it is not possible to test a total executive functioning score. Mean squares, partial ETA squares, and $\mathrm{f}$ values are presented in Table 5. Findings reveal that, age has no significant affect on any of the WCST scores where gender was found to be affecting WCST $4\left(\eta^{2}=.085, p=.02\right)$, 
WCST $9\left(\eta^{2}=.170, p=.001\right)$ WCST $12\left(\eta^{2}=.127, p=.006\right)$ and WCST $13\left(\eta^{2}=.107, p=.01\right)$.

Early special education background was found to be significantly affecting WCST scores 1, 3, $4,5,6,8$, and $13(p<.05)$.

Table 4. Factor analysis of WCST scores of participants in the study

\begin{tabular}{lcc}
\hline WCST score & Factor 1 & Factor 2 \\
\hline WCST 2 (Number of total errors) & .968 & \\
WCST 6 (Number or total perseverative errors & .926 & \\
WCST 5 (Number of perseverative responses) & .919 & \\
WCST 8 (Percentage of perseverative errors) & .872 & \\
WCST 11 (Percentage of conceptual level responses) & -.870 & .265 \\
WCST 10 (Number of conceptual level responses) & -.719 & .593 \\
WCST 1 (Number of total responses) & .635 & .571 \\
WCST 7 (Number of nonperseverative errors) & .586 & -.321 \\
WCST 4 (Number of categories completed) & -.423 & -.772 \\
WCST 13 (Learning to learn) & -.269 & -.765 \\
WCST 3 (Number of total corrects responses) & -.614 & .628 \\
WCST 12 (Failure to maintain a set) & -.214 & .387 \\
WCST 9 (Number of responses to complete the first set) & & .248 \\
& & \\
Explained variance \% & 39,49 & 28,48 \\
\hline Total variance \% & 39,49 & 67,98 \\
\hline
\end{tabular}


Table 5. General linear model. Combined affect of age, gender and early special education background on executive functioning

\begin{tabular}{|c|c|c|c|c|c|c|c|c|c|c|c|c|}
\hline \multirow[b]{2}{*}{$W C S T$} & \multicolumn{4}{|c|}{ Age } & \multicolumn{4}{|c|}{ Gender } & \multicolumn{4}{|c|}{ Early special education } \\
\hline & $\begin{array}{c}\text { Mean } \\
\text { squares }\end{array}$ & $f$ & $\begin{array}{c}\text { Partial } \\
\dot{\eta}^{2}\end{array}$ & $p$ & $\begin{array}{c}\text { Mean } \\
\text { squares }\end{array}$ & $f$ & $\begin{array}{c}\text { Partial } \\
\dot{\eta}^{2}\end{array}$ & $p$ & $\begin{array}{c}\text { Mean } \\
\text { squares }\end{array}$ & $f$ & $\begin{array}{c}\text { Partial } \\
\dot{\eta}^{2}\end{array}$ & $p$ \\
\hline WCST 2 & 55.02 & .29 & .005 & .59 & 198.27 & 1.04 & .018 & .31 & 390.14 & 2.28 & .04 & .13 \\
\hline WCST 3 & 15.31 & .12 & .002 & .72 & 22.35 & .18 & .003 & .66 & 390.48 & 3.81 & .06 & .05 \\
\hline WCST 5 & 2.51 & .14 & .007 & .84 & 134.75 & 1.42 & .024 & .23 & 789.32 & 9.91 & .15 & .003 \\
\hline WCST 6 & 20.38 & .21 & .004 & .64 & 182.85 & 1.93 & .033 & .16 & 867.33 & 11.22 & .16 & .001 \\
\hline WCST 7 & 57.40 & 1.52 & .026 & .22 & .327 & .09 & .001 & .92 & 95.98 & 2.65 & .04 & .10 \\
\hline WCST 8 & 59.84 & 1.25 & .022 & .26 & 6.68 & .14 & .002 & .70 & 396.37 & 9.85 & .15 & .003 \\
\hline WCST 12 & 1.93 & 1.54 & .026 & .22 & 10.38 & 8.25 & .127 & .006 & 5.81 & 5.07 & .08 & .02 \\
\hline WCST 13 & 163.91 & 2.61 & .044 & .11 & 430.81 & 6.85 & .107 & .01 & 2565.52 & 139.08 & .71 & .001 \\
\hline
\end{tabular}


Univariate analysis of variance among the children, total BDHI score as the dependent variable and each WCST scores as factors, yielded no significant differences $(\mathrm{df}=1, p<.05)$. Bonferroni post-hoc tests were ran in order to find out the possible differences between the groups in the study. Results showed no difference between groups. These findings reveal that executive functioning has no impact on the aggressive behaviours of the children in the study.

Table 6. ANOVA results of aggression scores and executive functions

\begin{tabular}{cccc}
\hline WCST & Mean squares & $f$ & Sig. \\
\hline WCST 1 & 8.24 & 1.64 & .20 \\
WCST 2 & 6.47 & 1.29 & .26 \\
WCST 3 & 6.55 & 1.30 & .26 \\
WCST 4 & 2.71 & .54 & .46 \\
WCST 5 & 1.14 & .22 & .63 \\
WCST 6 & 2.92 & .58 & .44 \\
WCST 7 & 3.47 & .69 & .41 \\
WCST 8 & 6.17 & 1.23 & .27 \\
WCST 9 & .59 & .12 & .73 \\
WCST 10 & 3.90 & .78 & .38 \\
WCST 11 & 3.66 & .73 & .39 \\
WCST 12 & 7.64 & 1.52 & .22 \\
WCST 13 & 2.93 & .58 & .44 \\
\hline Significance level $p<.05^{*}$ & &
\end{tabular}

\section{Discussion and Conclusions}

Present study assessed the effect of early special education background on the executive functions and aggressive behaviors of children who are deaf. Findings revealed that; early special education has no significant impact on the aggressive behaviors of school age children who are deaf. This finding might be the result of additional factors than language and communication skills. A reason might be the age range of children in the study. Participants were at adolescent period and possibly having psychological and physical changes. Such changes may lead to aggressive behaviors unrelated to language development and communication skills. Thus, even early special education background has positive effects on their language development; the impact of their transition period is possibly more dominant to suppress the positive effects of their language abilities. 
Findings on aggressive behaviors and gender present similar results to the literature on the aggressive behaviors of children who are deaf. Andersson and colleagues (2000), in their study assessed 57 children who are deaf and found that there are no gender differences in children who are deaf in terms of aggressive behaviors. Similarly, Sipal (2002) tested 152 normally developing and 147 hearing impaired children and reported that even though normally developing children showed significant gender differences for aggressive behaviors, such finding remained insignificant for the children who are deaf. Although literature lacks of studies directly assessing the aggressive behaviors of children who are deaf, limited studies present parallel results. Therefore, it is possible to generalize this finding for deaf children.

Starting from early childhood, social relationships enlarge over the boundaries of family and immediate environment. This enlargement leads to certain changes in friend choices and play types followed by different behavior structures. Aggressive behaviors emerging during preschool period are often the reflection of egocentric cognitive functioning. Nonetheless, starting from school age, origin of such aggressive behaviors leaves its place to social issues such as; acting against rules or trying to be a member of a group, even for not being able to be a member of a group (Taylor, Peplau, \& Sears, 2000). Besides, aggressive behaviors during adolescence are more self-oriented such as identity confusion or emotional breakdowns (Taylor, Pham, Rivkin \& Armor, 1998). However, findings of our study on age and aggression lead us to a different orientation for this issue. Deaf children between 10-14 ages do not differ in their aggressive behaviors and that finding might be a result of facing relatively similar problems within their social group. As normally developing adolescents' aggressive behaviors vary from a simple expression of the self to complex personality problems, one might say children who are deaf still struggle with their disability related problems during pre-adolescence and adolescence periods.

Literature shows no tracks presenting WCST factor distribution for deaf population. Therefore, we were interested how the WCST scores were distributed into factors and which factor is dominant for deaf population. According to the factor analysis of WCST scores for the participants, first factor measures perseveration and second factor measures working memory. This finding is parallel with the studies of WCST with normally developing children (Erol et al., 2006). Besides, WCST studies with adults present similar results as well. Karakas, Eski and Basar (1996) in their study also found that WCST scores were distributed in two factors and first factor was found to be measuring perseveration and the second factor was 
found to be measuring working memory. This finding shows that WCST dominantly measures perseveration for both normally developing population as well as hearing impaired individuals. Unfortunately it is not possible to find a research in the literature studied executive functioning of deaf adults thus, the findings can not be compared.

Results on early special education background were found to be having impact on executive functions. Findings present that WCST 1, 3, 4, 5, 6, 8 and 13 were significantly affected by special education background and group with early special education background was found to be having higher levels of executive functions. This finding links previous studies on impulsive responses of children who are deaf (Andersson et al., 2000; Sipal, 2002; Vandell \& George, 1981) and studies on executive functions and language problems (Hooper et al., 2002; Landa \& Goldberg, 2005; Marlowe, 2000; Singer \& Bashir, 1999). Andersson and collegues (2000) reported that children who are deaf have more impulsive responses than their normally hearing counterparts. Besides, Remmel (1999) in his study discussed deaf children having impulsive or aggressive behaviors due to language abilities have significant executive function delays. Similarly, Hooper and friends (2002) studied language skills and reported that impairments in language results in impairments in executive functions. The parallel finding in our study echoes the early studies and reveals that children who are deaf have delays in executive functions and better language abilities have a boosting effect in developing executive functions.

WCST scores $1,4,9,12,13$ were found to be significantly affected by gender, which show that gender has a significant impact on working memory for this study. However, this finding is on the contrary to the literature. Heaton (1993), Roselli and Ardilla (1993) and Shu, Tien, Lung and Chang (2000) reported that gender has no significant affect on executive functioning. Moreover, Erol and her collegues (2006) in the standardization of WCST for Turkish children reported that gender has no effect on any WCST scores. Such a finding in our study might be strongly related to the sample. In our study, we assessed a highly specific sample which may lead to biased findings because of the characteristics of the participants. However, this result is strongly considered by the authors as to be assessed in a further study.

Frontal lobs are well-known as the latest developing body structures anatomically and functionally and therefore, their activities increase by age and reach the top during adolescence (Karakas, 2004; Kilic, 2002). Thus, adolescents are expected to have higher levels of 
executive functioning and higher WCST scores than school age children. In our study, none of the WCST scores were found to be affected by age. This finding is critical for assessing the executive functions of deaf children as early studies discuss the importance of age in the development of executive functions (Erol et al., 2006; Heaton, 1993; Roselli and Ardilla, 1993). It is reported that normally developing children has the highest level of executive functioning around 11-12 ages and children who are deaf show delays in the development of executive functioning and have a 10 years old child's executive functioning when they are between 12 14 ages. Such a difference highlights the importance of language skills on the development of EF. As children learn to control their behaviours and flexibly correct their actions with social feedbacks (Hughes \& Graham, 2002), receiving insufficient feedback due to low language skills affect learning to control their responses. As a result one can say that "lack of practicing" self regulatory skills lead to delays in the development of EF.

Findings of our study presents that early special education experience has no significant impact on the aggressive behaviors of children who are deaf but their executive functions. From a theoretical perspective, the findings support the interdependence of language and executive functions but also suggest that executive functions themselves may be dissociable. Therefore, one can say that early special education has positive effects on cognitive development of children who are deaf, however, lacks of supporting social development due to social changes by age. As children have social problems during adolescence, their aggressive behaviors should be assessed deeply concerning every possible variables that are possibly affecting them.

Besides, it is argued that the behavioral manifestations of executive function delays observable in deaf children are unlikely to be the consequences of deafness itself but rather result from the language delays that are the consequences of the deafness. The finding that deaf children experience deficits in executive functions has both clinical and educational implications. Clinical assessment of deaf children should take into account their potential difficulties with executive functions and the ways in which this might interfere with their performance in other areas, including both the cognitive and social domains. Deficits in executive functions may be manifest in difficulties organizing thoughts for writing tasks, organizing materials for lessons or homework, organizing time, and implementing lengthy verbal instructions. Poor executive functioning may also show behaviorally through difficulties in social situations, such as expressing the self and peer interactions. Behavioral management and 
classroom teaching may be facilitated by using learning strategies that emphasize visual cues and place minimal demands on language, so that deaf children's executive functioning can be maximized. In addition, enhancing particular aspects of language use, such as teaching deaf children to practice and implement self talk strategies for planning and problem solving, may help them make better use of their existing executive functioning and develop them more fully.

This study was an attempt to assess the executive functions of children who are deaf and to clarify the linking to their aggressive behaviors and language abilities. As some of the findings echo the earlier researches, we also discussed some of the findings which are in contrary to the literature. However, present study has several questions rising for further research and evaluation to be addressed because of a number of limitations.

Limited number of participants in the studies has the risk of presenting biased results as well as decreasing the possibility of generalizing the findings. In a small group of participants, findings may reflect the characteristics of the participants, the cultural background they have or the structure of their social environment. Such possibilities may also be affecting the findings of our study as 82 children were included. A further study with a larger sample may present more accurate results.

Children with disabilities differ within their groups as they may have different levels of severity in their disability. Particularly for children who are deaf, there are numerous educational options according to their hearing and language abilities that support their development. As different educational backgrounds may cause differences in their developmental pace, including a particular group (only with severe hearing loss or only profound hearing loss) in a study may result in limited findings which are not comparable. Therefore, a future study including children who are deaf from different levels of hearing loss would provide deeper understanding of their aggressive behaviors and executive functioning.

Our study provides information on the development of executive functioning of children who are deaf. However, our findings are limited to a small range of age group. A further study including a wide range of age group (i.e. 6-12 ages) may provide clearer results on the development of the executive functions of children who are deaf. Besides, a comparison 
group would provide precious information on their developmental pathways in terms of executive functioning.

\section{References}

American Guidance Services Publishing (2005). Peabody Picture Vocabulary Test, $3^{\text {rd }}$ Edition. Retrieved September 11, 2008, from http://www.agsnet.com/group.asp?n GroupInfoID $=\mathrm{a} 12010$

Andersson, G., Olsson, E., Rydell, A. M. \& Larsen, H. C. (2000). Social Competence and Behavioral Problems in Children With Hearing Impairment. Audiology, 39, 88-92.

Askin, M. (1981). Bazı kişilik değişkenlerinin kültürlerarası sosyal psikolojik açıdan incelenmesi. [An investigation of some personality variables in terms of intercultural social psychology]. Unpublished doctoral dissertation, Ataturk University, Erzurum.

Baddeley, A. (1998). The central executive: A concept and some misconceptions. Journal of the International Neuropsychological Society, 4, 523-526.

Baker-Hawkins S. \& Easterbrooks S. (1994). Deaf and Hard of Hearing Students: Educational Service Delivery Guidelines. Alexandria, VA: National Association of State Directors of Special Education.

Berg, E.A. (1948). A simple objective technique for measuring flexibility in thinking. Journal of General Psychology, 39, 15-22.

Das, J. P., \& Ojile, E. (1995). Cognitive processing of students with and without hearing loss. Journal of Special Education, 29, 323-336.

Erol, N., Akcakın, M., Akozel-Sahin, A., Dikmeer-Altınoglu, I. ve Irak, M. (2006). Yönetici İşlevleri Değerlendirmede Kullanılan Nöropsikolojik Testlerin İlköğretim Çă̆ Çocukları Iç̧in Türk Kültürüne Standardizasyonu ve Güvenirlik Çalışması. [Standardization of neuropsychological tests used for assessing executive functions for Turkish school age children] Ankara Üniversitesi Bilimsel Araştırma Projeleri. Proje no: 20040809183, Ankara.

Esteban, M., Sidera, F., Serrano, J., Amado, A. \& Rostan, C. (2010). Improving social understanding of preschool children: Evaluation of a training program. Electronic Journal of Research in Educational Psychology, 8(2), pp.841-860. 
Fundudis T, Kolvin I, \& Garside R. (1979). Speech retarded and deaf children. The Hogarth Press, London.

Garavan, H., Ross, T. J., Murphy, K., Roche, R. A. P., \& Stein, E. A. (2002). Dissociable executive functions in the dynamic control of behavior: Inhibition, error detection and correction. Neuroimage, 17, 1820-1829.

Heaton, R.K. (1981). Wisconsin Card Sorting Test Manual. Odessa (F.L): Psychological Assessment Resources.

Heaton, R.K. (1993). Wisconsin Card Sorting Test Computer version 2.0. Odessa (F.L): Psychological Assessment Resources.

Hindley P. (2000). Child and adolescent psychiatry. In: Mental Health and Deafness (Eds P. Hindley \& N. Kitson), pp. 42 - 74. Whurr Publishers, London.

Hooper, S. R., Swartz, C. W., Wakely, M. B., deKruif, R. E. L. \& Montgomery, J. W. (2002). Executive functions in elementary school children with and without problems in written expression. Journal of Learning Disabilities, 35(1), 57-68.

Howley, M. \& Howe, C. (2004). Social interaction and cognitive growth: An examination through the role-taking skills of deaf and hearing children. British Journal of Developmental Psychology, 22(2), 219-243.

Hughes, C., \& Graham, A. (2002). Measuring executive functions in childhood: problems and solutions? Child and Adolescent Mental Health, 7, 131-142.

Karakas, S. (2004). Bilnot Bataryası El Kitabı: Nöropsikolojik testler için araştırma ve geliştirme çalışmaları, [Handbook of Bilnot Battery: Research and development studies of neuropsychological tests] Dizayn Ofset, Ankara.

Karakas, S. \& Aydin, H. (1999). Sizofrenide bilgi işleme bozuklukları. [Information processing disorders in schizophrenia]. Şizofreni dizisi, 2(4), 132-152.

Karakas S., Eski R. \& Basar E. (1996). Türk kültürü için standardizasyonu yapılmış nöropsikolojik testler topluluğu: BILLNOT Bataryast. [Bilnot Battery: The group of neuropsychological tests which were standardized for Turkish culture] Ulusal Nöroloji Kongresi Kitabı, Ufuk Matbaası, İstanbul. 
Assessing the link between executive functions and aggressive behaviours of children who are deaf: Impact of early special education

Khan, S., Edwards, L., \& Langdon, D. (2005). The cognition and behavior of children with cochlear implants, children with hearing aids and their hearing peers: A comparison. Audiology and Neuro-otology, 10, 117-126.

Kilic, B. G. (2002). Yönetici işlevler ve dikkat süreçlerine ilişkin kuramsal modeller ve nöroanotomi. [Theoretical models for executive functions and attention processes and neuroanatomy]. Klinik Psikiyatri (Turkish Journal of Clinical Psychiatry), 5, 105-110.

Kilincaslan, A. (2010). Dikkat eksikliği ve hiperaktivite bozukluğunda yürütücü işlevler. [Executive functioning in attention deficit and hyperactivity disorder]. Turkiye Klinikleri, Pediatrik Bilimler, 6(2), 15-21.

Landa, R. J. \& Goldberg, M. C. (2005). Language, Social and Executive Functions in High Functioning Autism: A Continuum of Performance. Journal of Autism and Developmental Disorders, 35(5), 557-573.

Lezak, M. D. (1995). Neuropsychological Assessment, 3rd ed. New York: Oxford University Press.

Lundy, J. E. B. (2002). Age and language skills of deaf children in relation to theory of mind development. Journal of Deaf Studies and Deaf Education, 7(1), 41-56.

Marschark, M., \& Everhart, V. S. (1999). Problem solving by hearing impaired and hearing children: Twenty questions. Hearing impairment and Education International, 1, 6379.

Marlowe, W. B. (2000). An Intervention for Children With Disorders of Executive Functions. Developmental Neuropsychology, 18(3), 445-454.

Meadow-Orlans K. \& Erting C. (2000) Deaf people in society. In: Mental Health and Deafness (Eds. P. Hudley \& N. Kitson), pp. 3 - 24. Whurr Publishers, London.

Mitchell, T. V., \& Quittner, A. L. (1996). Multi method study of attention and behavior problems in hearing impaired children. Journal of Clinical Child Psychology, 25, 83-96.

Miyake, A., Friedman, N. P., Emerson, M. J., Witzki, A. H., Howerter, A., \& Wager, T. D. (2000). The unity and diversity of executive functions and their contribution to complex 'frontal lobe' tasks: A latent variable analysis. Cognitive Psychology, 41, 49-100. 
Moeller, M.P. (2000). Early intervention and language development in children who are deaf and hard of hearing. Pediatrics, 106(3), e43. Retrieved October 25, 2008, from www.pediatrics.org/cgi/content/full/106/3/e43.

ner, N. (1997). Türkiye'de Kullanılan Psikolojik Testler. Bir Basvuru Kaynaği. [Psychological tests used in Turkey: A source for researchers]. Istanbul: Bogazici Üniversitesi Matbaas1.

Oner, O. \& Aysev, A. (1999). Dikkat eksikliği ve hiperaktivite bozukluğu ve yürütücü işlevler. [Attention deficit hyperactivity disorder and executive functions]. Cocuk ve Ergen Ruh Sagligi Dergisi, 6(2), 114-120.

Remmel, E. (1999, October). Theory of mind and executive function: Some evidence from deaf children. Poster presented at the annual meeting of the Cognitive Development Society, Chapel Hill, NC.

Roselli, M. \& Ardilla, A. (1993). Developmental norms for the Wisconsin Card Sorting Test in 5- to 12- year old children. Clin Neuropsychol 7, 145-154.

Rutter M, Graham P, \& Yule W. (1970). A neuropsychiatric study in childhood, pp.35-36. Philadelphia: Lippincott.

Shannon, P. \& Anderson, P. R. (2008). Developmental screening in community health care centers and pediatric practices: an evaluation of the baby steps program. Intellectual and Developmental Disabilities, 46 (4), 281-289.

Shallice, T., \& Burgess, P. W. (1991). Deficits in strategy application following frontal lobe damage in man. Brain 114, 727-741.

Shu, B.C., Tien, A.Y., Lung, F.W. \& Chang, Y. Y. (2000). Norms for the Wisconsin Card Sorting Test in 6-11 year old children in Taiwan. Clin Neuropsychol 14(3), 275-286

Singer, B. D. \& Bashir, A. S. (1999). What are executive functions and self-regulation and what do they have to do with language disorders? Language, Speech, and Hearing Services in Schools, 30(3), 265.

Sismanlar, S. G., Coskun, A., Agaoglu, B., Zaimoglu, S., Karakaya, I. \& Yavuz, C. I. (2009). Şizofreni tanılı hastaların çocuklarında dikkat, bellek ve yürütücü işlevler. [Attention, Memory and Executive Functions in the Offspring of Schizophrenic Patients]. Klinik Psikiyatri Dergisi, 12(4), 161-171. 
Spielberger, C.D., Reheiser, E.C., \& Sydeman, S.J. (1995). Measuring the experience, expression, and control of anger. In H. Kassinove (Ed.), Anger disorders: Definitions, diagnosis, and treatment. (pp.49-67). Washington, DC: Taylor \& Francis.

Spreen, O. \& Strauss, E. (1998). A Compendium of Neuropsychological Tests: Administration, Norms and Commentary (2nd.ed.). New York: Oxford University Press.

Sipal, R.F. (2002). 7-11 Yaş Arası İşitme Engelli ve Normal İşiten Çocukların Sosyal Uyum Düzeylerinin Karşılaştırılması. [A comparison of 7-11 years old normally developing and hearing impaired children in terms of their social adaptation levels] Unpublished Master of Science thesis, Hacettepe University, Ankara.

Sunal, S. \& Cam, . (2005). kulöncesi dönem işitme engelli çocukların ruhsal uyum düzeylerinin incelenmesi. [A research on psychological adaptation level of hearing impaired children in preschool period]. Cocuk ve Genclik Ruh Sagligi Dergisi, 12(1), 11-18.

Taylor, S. E., Pham, L. B., Rivkin, I. D. \& Armor, D. A. (1998). Harnessing the imagination: Mental simulation, self regulation and coping. American Psychologist, 53, 429-439.

Taylor, S. E., Peplau, L. A. \& Sears, O. D. (2000). Social Psychology (10th ed.). New Jersey: Prentice-Hall Inc.

TUIK, (2002). Turkiye Ozurluler Araştırması. [Turkey Disabilities Survey]. State Institute of Statistics Printing Division, Ankara.

Vandell, D. L. \& George, L. B. (1981). Social interaction in hearing and deaf preschoolers: Succeses and failures in initations. Child development 52, 627-635.

Welsh, M. C., \& Pennington, B. F. (1988). Assessing frontal lobe functioning in children: Views from developmental psychology. Developmental Neuropsychology, 4, 199230.

Yesilyurt, S., Maner, F., Ceylan, E., Güler, J., Turkcan, A. \& Satmis, N. (2008). Paranoid şifozreni, paranoid olmayan şizofreni ve paranoid bozuklukta yürütücü işlevler. [Executive functions in paranoid schizophrenia, nonparanoid schizophrenia and paranoid disorder]. Turkiye'de Psikiyatri, 10(3), 79-88.

Yoshinaga-ltano C. \& Sedey, A. (1998). Early speech development in children who are deaf or hard-of-hearing: interrelationships with language and hearing. The Volta Review 100, $181-211$. 
Young, A., Hunt, R., Carr, G., Hall, A.M., McCracken, W., Skipp, A. \& Tattersall, H. (2005). Informed choice, deaf children and families - underpinning ideas and project development. Electronic Journal of Research in Educational Psychology, 3(3), pp.253-273 